\title{
Causes of maternal mortality at tertiary care hospital
}

\author{
Vijayalakshmi G. ${ }^{1}$, Usharani N. ${ }^{2 *}$, A. A. Khazi ${ }^{2}$ \\ ${ }^{1}$ Senior Specialist, District Hospital, Bellary, Karnataka, India \\ ${ }^{2}$ Department of Obstetrics and Gynecology, VIMS, Bellary, Karnataka, India \\ Received: 27 December 2016 \\ Accepted: 02 January 2017

\section{*Correspondence:} \\ Dr. Usharani N., \\ E-mail: ushadrrani@gmail.com \\ Copyright: ( ) the author(s), publisher and licensee Medip Academy. This is an open-access article distributed under \\ the terms of the Creative Commons Attribution Non-Commercial License, which permits unrestricted non-commercial \\ use, distribution, and reproduction in any medium, provided the original work is properly cited.
}

\begin{abstract}
Background: Maternal mortality is a vital index of quality and efficiency of obstetric service, prevailing in a country. Women comprise an important section of any population and during child bearing period, the threat to life is protected by various preventive and therapeutic measures and many a time by surgical intervention.

Methods: A thorough analysis of data collected. Information was obtained from case sheets, laboratory investigations. During the present study, total births include live births, still births and deaths due to abortions are also included, since it is 'one of the important causes of maternal deaths.

Results: According to the above table Eclampsia is the main cause of direct death. Out of 25vaginal deliveries 7 cases died due to PPH $(26.92 \%)$.

Conclusions: Maternal Mortality is a global problem every country in the world is facing. We need to target specific interventions for specific population.
\end{abstract}

Keywords: Causes, Maternal mortality, PIH

\section{INTRODUCTION}

Maternal death is a great tragedy in the life of a family. Child birth is a biological function which gives joy to the mother and the family. This turns into a tragedy when woman loses her life while performing this social obligation. Pregnancy and child birth are physiological processes but by no means risk free. In all societies, the family is the central nucleus for people for their lives, their dreams and their health. A woman in her role as mother forms the backbone of the family, yet 500,000 women continue to die every year in the world from pregnancy related causes because societies decide 'ot to invest on women's lives, women's unpaid work in the family and in reproductions does not feature in national accounting. The countries with appallingly high maternal mortality continue to invest more on war than on women's health. Although every woman has the fundamental right to survive while performing the physiological duty of pregnancy and child birth, she is being denied this right in most of the developing countries. With time taking away fast; towards $21 \mathrm{st}$ century India has made a breakthrough towards economical revival. But it will be a futile exercise, if the plight of our mothers is not sorted out at war footing. ${ }^{1,2}$

Maternal mortality is a vital index of quality and efficiency of obstetric service, prevailing in a country. Women comprise an important section of any population and during child bearing period, the threat to life is protected by various preventive and therapeutic measures and many a time by surgical intervention. Women during reproductive period have to undergo great stress and strain and require special care when a woman dies of child births; her family, her community and her nation as a whole suffer. Families forego her critical role in child bearing, household management and providing care for children and other family members. Communities lose a vital member. Children suffer most. When a mother dies surviving children are 3-10 times more likely to die within 2 years compared to children who live with both parents. ${ }^{3}$ 
What makes these continued tragic deaths even more unacceptable is that these deaths are largely preventable and measures to prevent them are surprisingly simple affordable and effective. The regular antenatal, Intranatal and post natal care, advice and health education to pregnant and lactating women regarding nutrition and immunization has brought down the MMR to a significantly low level in a society. The antenatal services planned in PHC, urban centers through lady health visitors, ANMS and not the least anganawadi workers and teachers directly isolate the high risk pregnancies and are referred to appropriate referral hospitals., ${ }^{4,5}$

The postnatal advice with regard to care of breasts, breast feeding and opportunity utilized to enlighten and motivate methods to accept family planning methods and small family norms, and indirectly bringing down the exposure to repeated pregnancies and attended risks contribute to tone down the MMR.

Apart from liberal blood transfusion, improved obstetric techniques in anesthesia and analgesia availability of anti microbials, wide spread use of maintenance fluid, electrolyte and acid base balance is the serious complications of pregnancy, labour and abortion have materially changed obstetric practice and its outcome. Equally important is the wide spread obstetric training continuing medical education, which have provided more and better qualified specialists, conducting mortality conferences, exchange of views regarding the common causes of maternal mortality and discussing about methods of control can reduce maternal mortality rate.

\section{METHODS}

The deaths were classified as per FIGOS classification as follows:

- Direct obstetric causes

- Indirect obstetric causes

- Non related causes

This study includes maternal deaths due direct obstetric causes and indirect causes only.

Death resulting from the complications of the pregnancy itself, labour or the puerperium. From intervention elected or required by the pregnancy resulting from the chain of events initiated by the complication or intervention or within 42 days termination of pregnancy irrespective of the duration of pregnancy. Deaths resulting from disease present before or developing during pregnancy which was obviously aggravated by the physiologic effects of the pregnancy and causes deaths.

\section{Exclusion criteria}

- Non obstetric deaths: Deaths resulting, from causes not related to the pregnancy nor to its complication or management.
- Death from accidental or incidental causes no way related to the pregnancy. E.g.: death from automobile accident and death from suicide.

The Proforma prepared contained - name, age of the patient, IP No, Date of admission, date of death, booked or unbooked, presenting complaints and details antenatal care (if any). Obstetric history including marital status, age at marriage, age at first pregnancy primi or multi, history of previous pregnancy and labour, complication during present pregnancy, past and present medical problems.

If additional information was needed the relatives of the deceased were interviewed. Gestational age at delivery or death, whether died without delivery, place and date of delivery, any intervention during delivery, mode of delivery, and complication of delivery and puerperium. Interval between admission and delivery, interval between admission and death, date and time of death. A thorough analysis of data collected. Information was obtained from case sheets, laboratory investigations. During the present study, total births include live births, still births and deaths due to abortions are also included, since it is 'one of the important causes of maternal deaths.

\section{RESULTS}

Table 1: Maternal mortality in relation to cause of death.

\begin{tabular}{|lll|}
\hline Cause of death & No. of deaths & Percentage \\
\hline HTN disorders & 18 & $33.96 \%$ \\
\hline $\begin{array}{l}\text { Obstetric } \\
\text { haemorrhage }\end{array}$ & 12 & $22.64 \%$ \\
\hline Anaemia & 04 & $7.547 \%$ \\
\hline Hepatitis & 04 & $7.547 \%$ \\
\hline Septicemia & 07 & $13.20 \%$ \\
\hline Thromboembolism & 01 & $1.8 \%$ \\
\hline Heart disease & 02 & $3.77 \%$ \\
\hline Others & 05 & $9.433 \%$ \\
\hline Total & 53 & $100 \%$ \\
\hline
\end{tabular}

Others:

- Inversion of Uterus

- Amniotic fluid embolism

- Post LSCS with blood transfusion reaction with ARF

- ARDS with left lower lobe pneumonia

According to present study $18(33.96 \%)$ deaths were due to HTN disorders in pregnancy.

According to present study, during the study period from December 2011 to May 2013, 25 deaths (47.17\%) had vaginal delivery. 2 deaths $(3.774 \%)$ had instrumental vaginal delivery. 18 deaths $(33.96 \%)$ had Em LSCS. 
Table 2: Maternal mortality in relation to mode of delivery.

\begin{tabular}{|lll|}
\hline Mode of delivery & No of deaths & Percentage \\
\hline Undelivered & 6 & $11.32 \%$ \\
\hline Vaginal delivery & 25 & $47.17 \%$ \\
\hline Em LSCS & 18 & $33.96 \%$ \\
\hline $\begin{array}{l}\text { Instrumental } \\
\text { (vaginal delivery) }\end{array}$ & 2 & $3.774 \%$ \\
\hline Abortion & 2 & $3.774 \%$ \\
\hline Total & 53 & 100 \\
\hline
\end{tabular}

Table 3: Causes of death following vaginal delivery.

\begin{tabular}{|lll|}
\hline Cause & No of deaths & Cause \\
\hline HTN disorders & 9 & $\begin{array}{l}\text { HTN } \\
\text { disorders }\end{array}$ \\
\hline $\begin{array}{l}\text { Obstetric } \\
\text { haemorrhage }\end{array}$ & 9 & $\begin{array}{l}\text { Obstetric } \\
\text { haemorrhage }\end{array}$ \\
\hline Anemia & 1 & Anemia \\
\hline Sepsis & 1 & Sepsis \\
\hline Hepatitis & 2 & Hepatitis \\
\hline Heart disease & 1 & $\begin{array}{l}\text { Heart } \\
\text { disease }\end{array}$ \\
\hline Thromboembolism & 1 & $\begin{array}{l}\text { Thrombo } \\
\text { embolism }\end{array}$ \\
\hline Others & 3 & Others \\
\hline Total & 27 & Total \\
\hline
\end{tabular}

Table 3 shows percentage of death that had vaginal delivery is $47.169 \%$ and undelivered are $11.32 \%$. Eclampsia is the main cause of direct death. Out of 25 vaginal deliveries 7 cases died due to PPH (26.92\%).

Table 4: Causes of death following emergency LSCS.

\begin{tabular}{|l|l|}
\hline Mode of death & No \\
\hline HTN & 5 \\
\hline Obstetric Hemorrhage & 3 \\
\hline Anemia & 1 \\
\hline Sepsis & 6 \\
\hline Heart disease & 1 \\
\hline Hepatitis & 0 \\
\hline Thromboembolism & 0 \\
\hline Others & 2 \\
\hline Total & 1 \\
\hline
\end{tabular}

According to present study during the study period from December 2011 to May 2013, 6 maternal deaths occurred due to septicemia following Em LSCS. 5 maternal deaths occurred due to hypertension following Em LSCS.

\section{DISCUSSION}

According to present study, among 53 maternal deaths during the study period from December 2011 to May 2013, $18(33.96 \%)$ deaths were due to HTN disorders in pregnancy. According to the study in above table, hemorrhage is the leading cause of the death within 6 hours after the admission to the hospital. Eclampsia was the second most common cause for maternal morbidity. Early hospitalization of high risk cases, especially grand multiparas and availability of adequate blood transfusion are essential to prevent such deaths.

Table 5: Comparison of maternal mortality in relation to cause of death (VIMS V/S Nirmala Sharma study).

\begin{tabular}{|lll|}
\hline Cause of death & No. of deaths & $\begin{array}{l}\text { No. of deaths } \\
\text { Peference } \\
\text { study }\end{array}$ \\
\hline HTN disorders & $18(33.96 \%)$ & $90(19.7 \%)$ \\
\hline $\begin{array}{l}\text { Obstetric } \\
\text { haemorrhage }\end{array}$ & $12(22.64 \%)$ & $112(24.6 \%)$ \\
\hline Anemia & $4(7.55 \%)$ & $58(12.7 \%)$ \\
\hline Hepatitis & $04(7.55 \%)$ & $25(5.4 \%)$ \\
\hline Septicemia & $07(13.20 \%)$ & $64(14 \%)$ \\
\hline Thromboembolism & $01(1.8 \%)$ & - \\
\hline Heart disease & $02(3.77 \%)$ & $12(2.6 \%)$ \\
\hline Others & $09(16.98 \%)$ & $94(20.9 \%)$ \\
\hline Total & $53(100 \%)$ & $455(100 \%)$ \\
\hline
\end{tabular}

Many patients were referred in moribund stage either after giving trial of labour by local untrained dais, or post LSCS with complications from other hospitals. The influence of patient's ignorance and poor transport facilities also contribute to emergency surgery apart from prolonged rupture of membranes more than 12 hours and interference outside the hospital. According to present study, percentage of death due to $\mathrm{PPH}$ is $11.32 \%$. All these deaths were due to blood loss could have been prevented if patients were to come before the deterioration of general condition. Once PPH has been identified, management may be considered to involve four components- all of which must be undertaken simultaneously; (Note the acronym relevant here C-Call for help; R-Resuscitation; M- Monitoring and investigation; D-Deal with bleeding $)^{7}$. According to present study during the study period from December 2011 to May 2013, deaths due to HTN disorders in pregnancy are $33.96 \%$. It must be stressed that killer eclampsia can be anticipated and prevented in most cases with attention to basic antenatal care. ${ }^{7}$ If patient with pre Eclampsia does not respond to indoor, hospital treatment with rest and antihypertensive therapy or if fetus is in jeopardy of intrauterine death it is best to terminate pregnancy instead of adopting the policy of procrastination. If Eclampsia occurs, prompt and effective arrests of convulsions, followed by delivery soon after, can considerably reduce both maternal and perinatal morbidity and mortality.

\section{CONCLUSION}

Most maternal deaths are avoidable as the health care solutions to prevent or manage complications are well 
known. All women need access to antenatal care in pregnancy, skilled care during childbirth, and care and support in the weeks of childbirth. It is particularly important that all births are attended by skilled birth professionals, as timely management and treatment can make the difference between life's and deaths.

Funding: No funding sources

Conflict of interest: None declared

Ethical approval: The study was approved by the Institutional Ethics Committee

\section{REFERENCES}

1. Baskett TF. Complications of the third stage of labour. In: Essential Management of Obstetrical Emergencies. 3rd ed. Bristol, England: Clinical Press; 1999:196-201.

2. Hytten FE, Paintin DB. Increase in plasma volume during normal pregnancy. J Obstet Gynaecol $\mathrm{Br}$ Common. 1963;70:402-7.

3. Prystowsky EN, Katz AM. Atrial Fibrillation in Textbook of Cardiovascular Medicine. Philadelphia: Lippincott-Raven. 1998:1661.

4. Castro MA, Fassett MJ, Reynolds TB, Shaw KJ, Goodwin TM. Reversible peripartum liver failure: a new perspective on the diagnosis, treatment, and cause of acute fatty liver of pregnancy, based on 28 consecutive cases. Am J Obstet Gynecol. 1999;181(2):389-95.

5. O'Connor DJ, Scher LA, Gargiulo NJ. Incidence and characteristics of venous thromboembolic disease during pregnancy and the postnatal period: a contemporary series. Ann Vasc Surg. 2011;25(1):914.

6. Harrison KA. Maternal mortality in anaemia in pregnancy. West Afr Med. 1975;92(Suppl 5):27-31.

7. Ghazi A, Ali T, Jabbar S, Siddiq NM. Perinatal mortality contributors in singleton gestation. J Coll Physicians Surg Pak. 2009;19:711-3.

8. Puolakka J, Janne O, Pakarinen A, Jarvinen A, Vihko R. Serum ferritin as a measure of iron stores during and after normal pregnancy with and without iron supplements. Acta Obstet Gynecol Scand Suppl. 1980;95:43-51.

Cite this article as: Vijayalakshmi G, Usharani N, Khazi AA. Causes of maternal mortality at tertiary care hospital. Int J Reprod Contracept Obstet Gynecol 2017;6:404-7. 